\title{
Kualitas Kompos Cacing Tanah Lumbricus Rubellus Pada Pakan dan Media Yang Berbeda
}

\author{
Endah Novita ${ }^{1}$, Emmy Uthanya Antang ${ }^{2)}$, Bambang S. Lautt ${ }^{1)}$ dan Panji Surawijaya ${ }^{1)}$ \\ 1) Jurusan Budidaya Pertanian, Fakultas Pertanian, Universitas Palangka Raya \\ 2) Jurusan Sosial Ekonomi Pertanian, Universitas Palangka Raya \\ Email: endahnovita038@gmail.com
}

\begin{abstract}
This research aims to 1). Find out the content of N, P, C-Organic, Na-exch, Mg-exch, K-exch, Ca-exch, CEC, and $\mathrm{pH}-\mathrm{H}_{2} \mathrm{O}$ on vermicompost on different feed and media, 2). Find out the effect of feeding types and types medium for growth and development of earthworm colonies Lumbricus rubellus. This study used a factorial Completely Randomized Design (CRD). The first factor is the type of feed with 2 levels: P1 = tofu dregs (150 grams) and P2 = cattle rumen (100 grams) while the second factor is the type of media with 2 levels: G0 = cow manure $(1.4 \mathrm{~kg})$ and $\mathrm{G} 1=\mathrm{cow}$ manure $(0.7 \mathrm{~kg})+$ peat soil $(0.7 \mathrm{~kg})$. From these treatments there were 4 treatment combinations, each of which was repeated 3 times, in order to obtain 12 experimental units. The weight of worms used is 50 grams per experimental unit. This research was conducted for 3 months from October to December 2019, located at the Experimental Garden of the Department of Agricultural Cultivation, Faculty of Agriculture, Palangka Raya University and Palangka Raya University Analytical Laboratory. The results showed that the results of laboratory analysis of nutrients in worm compost such as pH-H2O, N-total, Corganic, P-Bray, K-exch, Ca-exch, Mg-exch, Na-exch and CEC were found to have different results. There was an interaction between the type of feed and the type of media that had a very significant effect on the $\mathrm{pH}-\mathrm{H} 2 \mathrm{O}$ variable and the weight of the earthworm Lumbricus rubellus and on a single factor, namely the P-Bray, Caexch and $\mathrm{Na}$-exch variables. Whereas in the $\mathrm{N}$-total, $\mathrm{C}$-organic, $\mathrm{K}$-exch and $\mathrm{CEC}$ variables there was no significant effect then there was an interaction between the type of feed and the type of media which had a very significant effect on the final weight of Lumbricus rubellus earthworm, namely in the P1G1 treatment with a weight of 155.77 grams, in P1G0 treatment with a weight of 105.58 grams, and in P2G0 treatment with a weight of 90.83 grams, and the weight of Lumbricus rubellus earthworms had no significant effect, namely the P2G1 treatment with a weight of 47.56 grams.
\end{abstract}

Keywords : Lumbricus rubellus, Earthworm, Tofu Dregs, Cow Rumen, Cow Manure, Peat Soil.

\section{Pendahuluan}

Cacing tanah adalah salah satu jenis fauna kelompok hewan tingkat rendah, yang tidak bertulang belakang (invertebrata) yang merupakan kelompok annelid atau cacing bersegmen di mana hewan ini ditemukan pada lingkungan terrestrial basah di Indonesia. Di dunia ini terdapat kira-kira 1800 spesies cacing tanah yang telah diidentifikasi dan diklasifikasikan (Catalan, 1981). Budidaya cacing tanah akan menghasilkan produk berupa cacing itu sendiri yang dapat dimanfaatkan sebagai pakan memancing, pakan pada budidaya ikan secara langsung maupun diolah menjadi pelet, tepung cacing, obat-obatan, dan kosmetik (Warsa, 2000). Produk lain yang dapat pula dihasilkan dari budidaya cacing adalah pupuk kascing atau bekas cacing yang merupakan pupuk organik. Pupuk bekas cacing (kascing) atau kompos cacing diketahui memiliki kadar N 5-10\%, kadar P 32,20-168,02 $\mathrm{mg} / 100 \mathrm{~g}$, dan kadar K 117,06-862,41 mg/100 g (Suyono dan Aisyah, 2000).

Aktivitas cacing tanah berperan penting dalam ekosistem tanah melalui proses memakan dan mengeluarkan tanah dalam bentuk kascing, sehingga memperbaiki sifat fisik dan kimia tanah. Pada tanah mineral, cacing tanah mempengaruhi bobot isi tanah, meningkatkan pori total dan pori aerasi, sehingga cacing tanah disebut sebagai bioagregrat (Lavelle, 1994). Cacing tanah juga disebut sebagai biofabrik karena mempengaruhi struktur tanah melalui proses pencernaan, pemilihan partikel tanah berukuran kecil dan membentuk struktur yang spesifik. Peranan cacing tanah terhadap sifat kimia tanah melalui kascing yang dihasilkan sehingga dapat meningkatkan kesuburan tanah. Selain itu aktivitas cacing tanah mempengaruhi laju dekomposisi bahan organik tanah, sehingga dapat meningkatkan ketersediaan unsur hara dan kesuburan tanah (Subler et al., 1998). 
Pupuk bekas cacing (kascing) atau kompos cacing juga sebagai pupuk yang ramah lingkungan, aman untuk digunakan pemacu pertumbuhan dan produksi tanaman. Secara umum yang dapat dijadikan bahan pakan cacing berupa limbah-limbah organik, seperti limbah sayuran, serbuk gergaji atau sisa media jamur, limbah hijauan, kotoran ternak, pelepah, daun, batang dan bongkol pisang, limbah jerami padi, dan ampas tahu (Arifah, 2014).

Pada dasarnya dalam pemberian pakan cacing tanah tidak berbeda dengan jenis ternak lainnya. Beberapa jenis pakan harus mengandung protein, lemak, karbohidrat, vitamin, mineral dan zat-zat makanan lainnya yang mudah dicerna oleh cacing tanah sehingga sangat bermanfaat untuk pertumbuhan dan kesehatannya. Menurut Wiriano (1985) ampas tahu merupakan limbah dalam bentuk padatan dari bubur kedelai yang diperas dan tidak berguna lagi dalam pembuatan tahu dan cukup potensial dipakai sebagai bahan makanan ternak cacing, karena ampas tahu masih mengandung gizi yang baik dan dapat digunakan sebagai ransum ternak besar dan kecil. Ampas tahu diperkirakan dapat menjadi alternatif sebagai bahan pakan budidaya cacing tanah. Menurut Mursining (2016) kandungan gizi dalam ampas tahu adalah protein $21,23 \%$, lemak $16,22 \%$, karbohidrat $19 \%$, serat kasar 29,59\%, kadar abu 5,45\%, dan air 9,84\%.

Media atau sarang merupakan tempat tinggal cacing tanah. Di dalam media tersebut cacing tanah melakukan segala aktivitasnya seperti bergerak, makan, tumbuh, dan bereproduksi. Oleh karena itu, bahan media harus memenuhi syarat sebagai tempat hidup dan sebagai makanan (Pangkulun, 2010).

Faktor-faktor yang mempengaruhi proses biologis dalam pengomposan adalah nisbah $\mathrm{C} / \mathrm{N}$, kelembapan, ketersediaan oksigen, mikroorganisme, suhu, $\mathrm{pH}$, namun faktor-faktor yang mempengaruhi pengomposan tersebut yang terpenting adalah nisbah unsur $\mathrm{C} / \mathrm{N}$ dalam bahan kompos (Mashur, 2001). Nisbah C/N yang baik untuk kompos cacing adalah 20-40 (Djuarmani dkk, 2005 ).

\section{Bahan dan Metode}

Penelitian ini dilaksanakan selama 3 bulan dari bulan Oktober sampai dengan Desember 2019. Bertempat di Kebun Percobaan Jurusan Budidaya Pertanian Fakultas Pertanian Universitas Palangka Raya dan Laboratorium Analitik Universitas Palangka Raya.

Bahan yang digunakan pada penelitian ini adalah kotoran sapi, tanah gambut, air, limbah pemotongan sapi (rumen), limbah pabrik tahu (ampas tahu), kain kasa dan bibit cacing Lumbricus rubellus. Alat yang digunakan untuk pembuatan pupuk organik kompos cacing Lumbricus rubellus adalah baskom plastik ukuran $26 \mathrm{~cm} \times 19 \mathrm{~cm} \times 9 \mathrm{~cm}$, potongan batang bambu $5 \mathrm{~cm}$, rak baskom, timbangan analitik, thermometer, dan alat-alat laboratorium penunjang analisis unsur hara.

Penelitian ini menggunakan Rancangan Acak Lengkap (RAL) Faktorial yang terdiri dari dua faktor perlakuan. Faktor pertama yaitu jenis pakan yang terdiri dari 2 taraf yaitu: P1 : Ampas Tahu $(150 \mathrm{~g})$ dan P2 : Rumen Sapi (100 g) serta faktor kedua yaitu jenis media yang terdiri dari 2 taraf yaitu : G0 : Pupuk Kotoran Sapi $(1,4 \mathrm{~kg})$ dan G1 : Pupuk Kotoran Sapi $(0,7 \mathrm{~kg})+$ Tanah Gambut $(0,7 \mathrm{~kg})$.

\section{Hasil dan Pembahasan}

Berdasarkan Tabel 3, hasil analisis N-total kascing (\%) menunjukkan tidak adanya interaksi antara jenis pakan dan jenis media. Diketahui dari data tersebut pada pakan ampas tahu (P1) dengan media kotoran sapi (G0) yaitu 1,12 \% dan pada media kombinasi kotoran sapi dan tanah gambut (G1) yaitu $1,20 \%$. Pada pakan rumen sapi (P2) dengan media kotoran sapi (G0) yaitu 1,48 \% dan pada media kombinasi kotoran sapi dan tanah gambut (G1) yaitu 1,51\%. Dari data-data tersebut dapat terlihat hasil analisis tidak berpengaruh nyata. Dari Tabel 3 dapat diketahui bahwa rata-rata jumlah Nitrogen $(\mathrm{N})$ yang terkandung dalam kompos tersebut tergolong sedang. Di mana kandungan Nitrogen $(\mathrm{N})$ tertinggi terdapat pada perlakuan P2G1 yaitu 1,51\% dan yang terendah terdapat pada perlakuan P1G0 yaitu 1,12 \%. Menurut Kusuma (2014) besar kecilnya kandungan Nitrogen (N) yang ada tergantung dari bahan organik yang digunakan dalam pembuatan pupuk kompos.

Menurut Sriharti (2008), kadar nitrogen dibutuhkan mikroorganisme untuk memelihara dan pembentukan sel tubuhnya sendiri, sehingga kandungan nitrogen dalam bahan akan berkurang karena 
digunakan oleh mikroorganisme untuk pertumbuhan. Sedangkan pada data tertinggi kenaikan N-Total lebih disebabkan karena adanya proses ekskresi oleh mikroorganisme dan cacing.

Tabel 3. Hasil Analisis N-total Kascing (\%)

\begin{tabular}{cccc}
\hline \multirow{2}{*}{ Jenis Pakan (P) } & \multicolumn{3}{c}{ Jenis Media (G) } \\
\cline { 2 - 3 } & $\begin{array}{c}\text { Kotoran Sapi } \\
(\mathrm{G} 0)\end{array}$ & $\begin{array}{c}\text { Kombinasi kotoran sapi dan } \\
\text { tanah gambut (G1) }\end{array}$ & Rata-Rata \\
\hline Ampas Tahu (P1) & 1,12 & 1,20 & 1,16 \\
Rumen Sapi (P2) & 1,48 & 1,51 & 1,50 \\
\hline Rata-rata & 1,30 & 1,36 & \\
\hline
\end{tabular}

Berdasarkan Tabel 4, hasil analisis K-dd kompos cacing Lumbricus rubellus menunjukkan tidak adanya interaksi antara jenis pakan dan jenis media. Diketahui dari data tersebut pada pakan ampas tahu (P1) dengan media kotoran sapi (G0) yaitu 14,31 me/100 g dan pada media kombinasi kotoran sapi dan tanah gambut (G1) yaitu 13,98 me/100 g . Pada pakan rumen sapi (P2) dengan media kotoran sapi (G0) yaitu 13,82 me/100 g dan pada media kombinasi kotoran sapi dan tanah gambut (G1) yaitu 14,32 me/100 g . Menurut Sinuraya (2007), unsur kalium (K) merupakan unsur hara yang mudah mengadakan persenyawaan dengan zat lain, misalnya Ca dan $\mathrm{Mg}$. Sifat K yaitu mudah larut dan terbawa hanyut dan mudah pula difiksasi dalam tanah.

Tabel 4. Hasil Analisis K-dd Kascing (me/100 g)

\begin{tabular}{cccc}
\hline \multirow{2}{*}{ Jenis Pakan (P) } & \multicolumn{2}{c}{ Jenis Media (G) } & Rata-Rata \\
\cline { 2 - 3 } & $\begin{array}{c}\text { Kotoran Sapi } \\
(\mathrm{G} 0)\end{array}$ & $\begin{array}{c}\text { Kombinasi Kotoran sapi dan } \\
\text { tanah gambut (G1) }\end{array}$ & \\
\hline Ampas Tahu (P1) & 14,31 & 13,98 & 14,14 \\
Rumen Sapi (P2) & 13,82 & 14,32 & 14,07 \\
\hline Rata-rata & 14,07 & 14,15 & \\
\hline
\end{tabular}

Berdasarkan Tabel 5, hasil analisis C-Organik kascing (\%) menunjukkan tidak adanya interaksi antara jenis pakan dan jenis media. Diketahui dari data tersebut pada pakan ampas tahu (P1) dengan media kotoran sapi (G0) yaitu 42,24\% dan pada media kombinasi kotoran sapi dan tanah gambut (G1) yaitu $41,45 \%$. Pada pakan rumen sapi (P2) dengan media kotoran sapi (G0) yaitu 42,37d\% dan pada media kombinasi kotoran sapi dan tanah gambut (G1) yaitu 41,07\%. Pada hasil C-Organik atau bahan organik yang mana merupakan hasil dari pelapukan atau dekomposisi jenis pakan yang bercampur dengan bahan mineral lain di dalam pupuk atau media. Hasil analisis C-Organik pengaruh yang paling tinggi terletak pada jenis pakan rumen sapi. Hal ini dikarenakan pada jenis pakan tersebut mengandung bahan organik yang cukup tinggi bercampur dengan media kotoran sapi dan tanah gambut.

Tabel 5. Hasil Analisis C-Organik Kascing (\%)

\begin{tabular}{cccc}
\hline \multirow{2}{*}{ Jenis Pakan (P) } & \multicolumn{2}{c}{ Jenis Media (G) } & Rata-Rata \\
\cline { 2 - 3 } & $\begin{array}{c}\text { Kotoran Sapi } \\
(\mathrm{G} 0)\end{array}$ & $\begin{array}{c}\text { Kombinasi Kotoran sapi dan } \\
\text { tanah gambut (G1) }\end{array}$ & \\
\hline Ampas Tahu (P1) & 42,24 & 41,45 & 41,48 \\
Rumen Sapi (P2) & 42,37 & 41,07 & 41,72 \\
\hline Rata-rata & 42,31 & 41,26 & \\
\hline
\end{tabular}


Berdasarkan Tabel 6, hasil analisis Mg-dd kompos cacing Lumbricus rubellus menunjukkan tidak adanya interaksi antara jenis pakan dan jenis media. Diketahui dari data tersebut pada pakan ampas tahu (P1) dengan media kotoran sapi (G0) yaitu 1,81 me/100 g dan pada media kombinasi kotoran sapi dan tanah gambut (G1) yaitu 1,80 me/100 g. Pada pakan rumen sapi (P2) dengan media kotoran sapi (G0) yaitu 1,79 me/100 g dan pada media kombinasi kotoran sapi dan tanah gambut (G1) yaitu $1,78 \mathrm{me} / 100 \mathrm{~g}$.

Tabel 6. Hasil Analisis Mg-dd Kascing (me/100 g)

\begin{tabular}{|c|c|c|c|}
\hline \multirow[b]{2}{*}{ Jenis Pakan (P) } & \multicolumn{2}{|c|}{ Jenis Media (G) } & \multirow[b]{2}{*}{ Rata-Rata } \\
\hline & $\begin{array}{l}\text { Kotoran Sapi } \\
\text { (G0) }\end{array}$ & $\begin{array}{c}\text { Kombinasi Kotoran sapi dan } \\
\text { tanah gambut (G1) }\end{array}$ & \\
\hline Ampas Tahu (P1) & 1,81 & 1,80 & 1,81 \\
\hline Rumen Sapi (P2) & 1,79 & 1,78 & 1,78 \\
\hline Rata-rata & 1,80 & 1,79 & \\
\hline
\end{tabular}

Berdasarkan Tabel 7, hasil analisis KTK kompos cacing Lumbricus rubellus menunjukkan tidak adanya interaksi antara jenis pakan dan jenis media. Diketahui dari data tersebut pada pakan ampas tahu (P1) dengan media kotoran sapi (G0) yaitu 81,40 me/100 g dan pada media kombinasi kotoran sapi dan tanah gambut (G1) yaitu 87,71 me/100 g. Pada pakan rumen sapi (P2) dengan media kotoran sapi (G0) yaitu 87,12 me/100 g dan pada media kombinasi kotoran sapi dan tanah gambut (G1) yaitu 87,51 me/100 g. KTK merupakan kemampuan tanah dalam menjerap dan mempertukarkan kation dalam tanah, menurut Anwar dan Sudadi (2013) menyatakan bahwa KTK meningkat dipengaruhi oleh dekomposisi bahan organik yang menghasilkan senyawa humik. Senyawa ini dapat menyumbangkan koloid tanah yang mampu meningkatkan KTK dengan bertambahnya muatan negatif. Peningkatan KTK dapat menyebabkan tanah menjadi subur.

Tabel 7. Hasil Analisis KTK Kascing (me/100 g)

\begin{tabular}{cccc}
\hline \multirow{2}{*}{ Jenis Pakan (P) } & \multicolumn{2}{c}{ Jenis Media (G) } & Rata-Rata \\
\cline { 2 - 3 } & $\begin{array}{c}\text { Kotoran Sapi } \\
(\mathrm{G} 0)\end{array}$ & $\begin{array}{c}\text { Kombinasi Kotoran sapi dan } \\
\text { tanah gambut (G1) }\end{array}$ & \\
\hline Ampas Tahu (P1) & 81,40 & 87,71 & 84,56 \\
Rumen Sapi (P2) & 87,12 & 87,51 & 87,32 \\
\hline Rata-rata & 84,26 & 87,61 & \\
\hline
\end{tabular}

Berdasarkan Tabel 8, hasil analisis P Bray I Kascing (ppm) menunjukkan tidak adanya interaksi antara jenis pakan dan jenis media. Diketahui dari data tersebut pada pakan ampas tahu (P1) dengan media kotoran sapi (G0) yaitu 801,49 dan pada media kombinasi kotoran sapi dan tanah gambut (G1) yaitu 1119,90. Pada pakan rumen sapi (P2) dengan media kotoran sapi (G0) yaitu 1018,91 dan pada media kombinasi kotoran sapi dan tanah gambut (G1) yaitu 1324,25. Dari perhitungan analisis ragam faktor tunggal ditemukan hasil yang berpengaruh nyata pada media kombinasi kotoran sapi dan tanah gambut. Menurut Embleton et al., (1973) bahwa P berperan dalam pertumbuhan tanaman yaitu pada batang, akar, ranting, dan daun. P sendiri dibutuhkan oleh tanaman untuk pembentukan sel pada jaringan akar dan tunas yang sedang tumbuh memperkuat batang, sehingga tidak mudah rebah pada ekosistem alami (Thompson dan Troch 1978). 
Tabel 8. Hasil Analisis P Bray I Kascing (ppm)

\begin{tabular}{cccc}
\hline \multirow{2}{*}{ Jenis Pakan (P) } & \multicolumn{2}{c}{ Jenis Media (G) } & Rata-R ata \\
\cline { 2 - 3 } & $\begin{array}{c}\text { Kotoran Sapi } \\
(\mathrm{G} 0)\end{array}$ & $\begin{array}{c}\text { Kombinasi Kotoran sapi dan } \\
\text { tanah gambut (G1) }\end{array}$ & \\
\hline Ampas Tahu (P1) & 801,49 & 1119,90 & 960,69 \\
Rumen Sapi (P2) & 1018,91 & 1324,25 & 1171,58 \\
\hline Rata-rata & $910,20 \mathrm{a}$ & $1222,07 \mathrm{~b}$ & \\
\hline
\end{tabular}

BNJ $5 \% \mathrm{G}: 352,4$

Keterangan :Angka-angka pada baris dan kolom yang sama, yang diikuti oleh huruf yang sama menunjukkan tidak berbeda nyata menurut uji BNJ pada taraf $5 \%$

Berdasarkan Tabel 9, hasil analisis pH H2O Kascing (1:2,5) menunjukkan adanya interaksi antara perlakuan jenis pakan dengan jenis media yang menunjukkan bahwa faktor perlakuan jenis pakan dan jenis media dapat meningkatkan $\mathrm{pH}$ kompos cacing Lumbricus rubellus. Di mana perlakuan jenis media kombinasi kotoran sapi dan tanah gambut (G1) menghasilkan pH tertinggi dibadingkan dengan perlakuan jenis media hanya dengan kotoran sapi (G0). Diketahui dari data tersebut pada perlakuan pakan ampas tahu (P1) dengan media kotoran sapi (G0) yaitu 4,21 dan pada media kombinasi kotoran sapi dan tanah gambut (G1) yaitu 5,36. Pada perlakuan pakan rumen sapi (P2) dengan media kotoran sapi (G0) yaitu 4,68 dan pada media kombinasi kotoran sapi dan tanah gambut (G1) yaitu 5,47. Dari data-data tersebut dapat dilihat hasil analisis berbeda pada perlakuan P1G0. Pada perlakuan jenis media hasil yang lebih tinggi ditemukan pada media kombinasi kotoran sapi dan tanah gambut (G1).

Pada media G0 dan G1 hampir sama mirip atau berasal dari bahan yang sama. Tidak terlalu banyak terjadi perubahan pada $\mathrm{pH}$ karena terjadi dekomposisi. Dekomposisi menunjukkan proses dekomposisi berlangsung tanpa terjadi peningkatan suhu. Biasanya, $\mathrm{pH}$ agak turun pada awal proses pengomposan. Karena aktivitas bakteri yang menghasilkan asam. Dengan munculnya mikroorganisme lain dari bahan yang didekomposisi maka $\mathrm{pH}$ kembali naik setelah beberapa hari dan $\mathrm{pH}$ berada pada kondisi netral. Pada prinsipnya bahan organik dengan nilai pH antara 3 dan 11 dapat dikomposkan, $\mathrm{pH}$ optimum berkisar antara 5,5 dan 8. Mikroorganisme lebih menyukai pada $\mathrm{pH}$ netral. Kondisi sangat asam pada awal proses dekomposisi menunjukkan proses dekomposisi berlangsung tanpa terjadi peningkatan suhu. Biasanya, $\mathrm{pH}$ agak turun pada awal proses pengomposan karena aktivitas bakteri yang menghasilkan asam (Sutanto, 2002). Menurut Brata (2009) pH optimum untuk pertumbuhan cacing tanah adalah $\mathrm{pH}$ 5-7,2 yang merupakan $\mathrm{pH}$ optimum untuk bakteri bekerja.

Tabel 9. Hasil Analisis pH H2O Kascing (1:2,5)

\begin{tabular}{cccc}
\hline \multirow{2}{*}{ Jenis Pakan (P) } & \multicolumn{2}{c}{ Jenis Media (G) } & Rata-Rata \\
\cline { 2 - 3 } & $\begin{array}{c}\text { Kotoran Sapi } \\
(\mathrm{G} 0)\end{array}$ & $\begin{array}{c}\text { Kombinasi Kotoran sapi dan } \\
\text { tanah gambut (G1) }\end{array}$ & 4,79 \\
\hline Ampas Tahu (P1) & $4,21 \mathrm{a}$ & $5,36 \mathrm{c}$ & 5,08 \\
Rumen Sapi (P2) & $4,68 \mathrm{~b}$ & $5,47 \mathrm{~cd}$ & \\
\hline Rata-rata & 4,45 & 5,42 & \\
\hline \multicolumn{3}{c}{ BNJ 5\%:0,25 }
\end{tabular}

Keterangan: Angka-angka pada baris dan kolom yang sama, yang diikuti oleh huruf yang sama menunjukkan tidak berbeda nyata menurut uji BNJ pada taraf $5 \%$

Berdasarkan Tabel 10. Hasil analisis Ca-dd kompos cacing Lumbricus rubellus menunjukkan tidak adanya interaksi antara jenis pakan dan jenis media. Diketahui dari data tersebut pada pakan ampas tahu (P1) dengan media kotoran sapi (G0) yaitu 18,67 me/100 g dan pada media kombinasi kotoran sapi dan tanah gambut (G1) yaitu 14,68 me/100 g. Pada pakan rumen sapi (P2) dengan media kotoran sapi (G0) yaitu 17,16 me/100 g dan pada media kombinasi kotoran sapi dan tanah gambut 
(G1) yaitu 10,40 me/100 g. Dari data tersebut dapat terlihat perbedaan yang terletak pada kedua perlakuan dan harus dilanjutkan dengan uji BNJ $5 \%=2,45$. Dari perhitungan analisis ragam faktor tunggal ditemukan hasil yang berpengaruh sangat nyata pada perlakuan jenis media dan perlakuan jenis pakan, pada perlakuan jenis media ditemukan hasil yang lebih tinggi terletak pada media kombinasi kotoran sapi dan pada perlakuan jenis pakan hasil lebih tinggi ditemukan pada perlakuan paka ampas tahu.

Tabel 10. Hasil Analisis Ca-dd Kascing (me/100 g)

\begin{tabular}{cccc}
\hline \multirow{2}{*}{ Jenis Pakan (P) } & \multicolumn{2}{c}{ Jenis Media (G) } & Rata-Rata \\
\cline { 2 - 3 } & $\begin{array}{c}\text { Kotoran Sapi } \\
(\mathrm{G} 0)\end{array}$ & $\begin{array}{c}\text { Kombinasi Kotoran sapi dan } \\
\text { tanah gambut (G1) }\end{array}$ & $16,68 \mathrm{~b}$ \\
\hline Ampas Tahu (P1) & 18,67 & 14,68 & $13,78 \mathrm{a}$ \\
\hline Rumen Sapi (P2) & 17,16 & 10,40 & \\
\hline Rata-rata & $17,92 \mathrm{~b}$ & $12,54 \mathrm{a}$ & \\
\hline
\end{tabular}

BNJ 5\%:2,45

Keterangan :Angka-angka pada baris dan kolom yang sama, yang diikuti oleh huruf yang sama menunjukkan tidak berbeda nyata menurut uji BNJ pada taraf $5 \%$

Berdasarkan Tabel 11, hasil analisis Na-dd kompos cacing Lumbricus rubellus menunjukkan tidak adanya interaksi antara jenis pakan dan jenis media. Diketahui dari data tersebut pada pakan ampas tahu (P1) dengan media kotoran sapi (G0) yaitu 1,36 me/100 g dan pada media kombinasi kotoran sapi dan tanah gambut (G1) yaitu 1,47 me/100 g. Pada pakan rumen sapi (P2) dengan media kotoran sapi (G0) yaitu 1,87 me/100 g dan pada media kombinasi kotoran sapi dan tanah gambut (G1) yaitu $1,89 \mathrm{me} / 100 \mathrm{~g}$. Dari perhitungan analisis ragam faktor tunggal ditemukan hasil yang berpengaruh nyata pada pakan dan hasil yang paling tinggi ditemukan pada perlakuan pakan rumen sapi.

Tabel 11. Hasil Analisis Na-dd Kascing (me/100g)

\begin{tabular}{|c|c|c|c|}
\hline \multirow[b]{2}{*}{ Jenis Pakan $(\mathrm{P})$} & \multicolumn{2}{|c|}{ Jenis Media $(\mathrm{G})$} & \multirow[b]{2}{*}{ Rata-Rata } \\
\hline & $\begin{array}{l}\text { Kotoran Sapi } \\
(\mathrm{G} 0)\end{array}$ & $\begin{array}{c}\text { Kombinasi Kotoran sapi dan } \\
\text { tanah gambut (G1) }\end{array}$ & \\
\hline Ampas Tahu (P1) & 1,36 & 1,47 & $1,42 \mathrm{a}$ \\
\hline Rumen Sapi (P2) & 1,87 & 1,89 & $1,88 \mathrm{~b}$ \\
\hline Rata-rata & 1,62 & 1,68 & \\
\hline
\end{tabular}

Keterangan: Angka-angka pada baris dan kolom yang sama, yang diikuti oleh huruf yang sama menunjukkan tidak berbeda nyata menurut uji BNJ pada taraf $5 \%$

Berdasarkan Tabel 12 bobot akhir cacing Lumbricus rubellus menunjukkan adanya interaksi antara jenis pakan dan jenis media. Diketahui bobot cacing tertinggi terdapat pada perlakuan P1G1 dengan bobot 155,77 gram, pada perlakuan P1G0 dengan bobot 105,58 gram, dan pada perlakuan P2G0 dengan bobot 90,83 gram, dan bobot cacing tanah Lumbricus rubellus terendah atau mengalami penurunan yaitu pada perlakuan P2G1 dengan bobot 47,56 gram. perlakuan P1G1, P1G0 dan P2G0 berbeda dengan terhadap perlakuan P2G1. Pada perlakuan P1G1 cacing mengalami pertambahan bobot paling tinggi sebesar 105,77 gram, pada perlakuan P1G0 dengan pertambahan bobot 55,58 gram, pada perlakuan P2G0 dengan bobot 40,83 gram dan pada perlakuan P2G0 mengalami penurunan bobot yaitu 2,44 gram yang pada awal budidaya masing-masing perlakuan 50 gram. Pertambahan bobot cacing tanah dipengaruhi oleh unsur nitrogen $(\mathrm{N})$ yang terkandung pada setiap media pemeliharaan. Cacing tanah Lumbricus rubellus lebih menyukai tanah yang mengandung bahan organik tinggi dan pakan yang lebih halus. Penurunan bobot cacing tanah diduga karena kandungan 
nutrisi pada media tumbuh tidak mencukupi untuk pertumbuhan cacing sehingga menyebabkan cacing menjadi kurus atupun mati.

Tabel 12. Bobot Akhir Cacing Lumbricus rubellus (gram)

\begin{tabular}{cccc}
\hline \multirow{2}{*}{ Jenis Pakan (P) } & \multicolumn{2}{c}{ Jenis Media (G) } & Rata-Rata \\
\cline { 2 - 3 } & $\begin{array}{c}\text { Kotoran Sapi } \\
(\mathrm{G} 0)\end{array}$ & $\begin{array}{c}\text { Kombinasi Kotoran sapi dan } \\
\text { tanah gambut (G1) }\end{array}$ & \\
\hline Ampas Tahu (P1) & $105,58 \mathrm{bc}$ & $155,77 \mathrm{~d}$ & 130,67 \\
Rumen Sapi (P2) & $90,83 \mathrm{~b}$ & $47,56 \mathrm{a}$ & 69,19 \\
\hline Rata-rata & 98,20 & 101,66 & \\
\hline
\end{tabular}

BNJ $5 \%: 18,85$

Keterangan: Angka-angka pada baris dan kolom yang sama, yang diikuti oleh huruf yang sama menunjukkan tidak berbeda nyata menurut uji BNJ pada taraf $5 \%$

Berdasarkan Tabel 13, hasil C/N Rasio kompos cacing diketahui pada perlakuan P1G0 C/N Rasio 37,71, pada perlakuan P1G1 yaitu 34,54, pada perlakuan P2G0 28,62, dan pada perlakuan P2G1 27,19. Dengan demikian dapat disimpulkan bahwa C/N Rasio kompos cacing belum memenuhi kriteria kompos SNI 19-7030-2004 yaitu 10 hingga 20, dan Permentan No 01 tahun 2019 yaitu $\leq 25$. $\mathrm{C} / \mathrm{N}$ Rasio merupakan faktor paling penting dalam proses pengomposan. Hal ini disebabkan oleh proses pengomposan tergantung dari kegiatan mikroorganisme yang membutuhkan karbon sebagai sumber energi dan pembentuk sel.

Tabel 13. C/N Rasio kompos cacing

\begin{tabular}{cccc}
\hline \multirow{2}{*}{ Jenis Pakan (P) } & \multicolumn{2}{c}{ Jenis Media (G) } & Rata-Rata \\
\cline { 2 - 3 } & $\begin{array}{c}\text { Kotoran Sapi } \\
(\mathrm{G} 0)\end{array}$ & $\begin{array}{c}\text { Kombinasi Kotoran sapi dan } \\
\text { tanah gambut (G1) }\end{array}$ & \\
\hline Ampas Tahu (P1) & 37,71 & 34,54 & 35,75 \\
Rumen Sapi (P2) & 28,62 & 27,19 & 27,81 \\
\hline Rata-rata & 32,5 & 30,34 & \\
\hline
\end{tabular}

Suhu mempengaruhi jenis mikroorganisme yang hidup di dalam media. Menurut Ruskandi (2006) dalam proses pengomposan aerobik terdapat dua fase yaitu fase mesofilik $23-45^{\circ} \mathrm{C}$ dan fase termofilik $45-65^{\circ} \mathrm{C}$. Kisaran temperatur ideal tumpukan kompos adalah $55-65^{\circ} \mathrm{C}$. Menurut Indriani (2007) suhu optimal dalam proses pengomposan adalah $30-50^{\circ} \mathrm{C}$, sedangkan menurut kriteria SNI 2004, suhu ideal proses pengomposan maksimal $50^{\circ} \mathrm{C}$. Peningkatan suhu terjadi karena aktivitas bakteri dalam mendekomposisi bahan organik. Kondisi mesofilik lebih efektif karena aktivitas mikroorganisme didominasi protobakteri dan fungi. Pembalikan yang dilakukan dalam proses pengomposan mengakibatakan temperatur turun dan kemudian naik lagi (Pandebesie \& Rayuanti, 2013).

Tabel 14. Rata-rata Suhu Media Selama 1 Bulan $\left({ }^{\circ} \mathrm{C}\right)$

Pengamatan Suhu Minggu Pertama

28 Oktober 2019

\begin{tabular}{ccccc}
\hline No & Sampel & Pagi & Siang & Sore \\
\hline 1 & G0P1 & 24,7 & 30,0 & 29,2 \\
2 & G0P2 & 24,6 & 30,6 & 30,0 \\
3 & G1P1 & 24,5 & 29,7 & 29,3 \\
4 & G1P2 & 24,4 & 30,3 & 29,3 \\
\hline
\end{tabular}




\begin{tabular}{|c|c|c|c|c|}
\hline \multicolumn{5}{|c|}{$\begin{array}{c}\text { Pengamatan Suhu Minggu Kedua } \\
4 \text { November } 2019\end{array}$} \\
\hline No & Sampel & Pagi & Siang & Sore \\
\hline 1 & G0P1 & 24,2 & 30,6 & 30,6 \\
\hline 2 & G0P2 & 24,6 & 30,4 & 30,5 \\
\hline 3 & G1P1 & 24,5 & 30,7 & 30,4 \\
\hline 4 & G1P2 & 24,5 & 30,1 & 30,5 \\
\hline \multicolumn{5}{|c|}{$\begin{array}{c}\text { Pengamatan Suhu Minggu Ketiga } \\
11 \text { November } 2019\end{array}$} \\
\hline No & Sampel & Pagi & Siang & Sore \\
\hline 1 & G0P1 & 27,5 & 30,0 & 30,5 \\
\hline 2 & G0P2 & 27,3 & 30,1 & 30,3 \\
\hline 3 & G1P1 & 27,4 & 30,2 & 30,8 \\
\hline 4 & G1P2 & 27,3 & 29,9 & 30,2 \\
\hline \multicolumn{5}{|c|}{$\begin{array}{c}\text { Pengamatan Suhu Minggu Keempat } \\
18 \text { November } 2019\end{array}$} \\
\hline No & Sampel & Pagi & Siang & Sore \\
\hline 1 & G0P1 & 27,8 & 30,3 & 29,7 \\
\hline 2 & G0P2 & 27,9 & 30,9 & 30,2 \\
\hline 3 & G1P1 & 27,6 & 30,2 & 29,8 \\
\hline 4 & G1P2 & 27,9 & 30,5 & 29,6 \\
\hline
\end{tabular}

Berdasarkan Tabel 15 Hasil analisis kompos cacing dengan baku mutu pupuk organik permentan No 01 Tahun 19 diketahui bahwa hasil kompos cacing pada parameter $\mathrm{pH}$ telah memenuhi kriteria sebesar 5,42 yaitu pada perlakuan jenis media kombinasi kotoran sapi dengan tanah gambut. Pada parameter C-Organik juga telah memenuhi kriteria sebesar $41,72 \%$ yaitu pada perlakuan jenis pakan rumen sapi. Pada parameter C/N Rasio dengan nilai 35,75 belum memenuhi kriteria baku mutu pupuk organik dan pada ada parameter $\mathrm{N}$ Total juga belum memenuhi kriteria.

Tabel 15. Hasil Analisis Kompos Cacing Dengan Baku Mutu Permentan

\begin{tabular}{lcccl}
\hline No & Parameter & Nilai & Baku Mutu & \multicolumn{1}{c}{ Keterangan } \\
\hline 1 & $\mathrm{pH}$ & 5,42 & $4-9$ & Memenuhi kriteria \\
2 & C-Organik & $41,72 \%$ & $15 \%$ & Memenuhi kriteria \\
3 & C/N Rasio & 35,75 & $\leq 25$ & Belum memenuhi kriteria \\
4 & N Total & $1,50 \%$ & $2 \%$ & Belum memenuhi kriteria \\
\hline
\end{tabular}

\section{Kesimpulan}

1. Hasil analisis laboratorium unsur hara pada kompos cacing seperti $\mathrm{pH}-\mathrm{H}_{2} \mathrm{O}, \mathrm{N}$-total, C-organik, P-Bray, K-dd, Ca-dd, Mg-dd, Na-dd dan KTK diketahui memiliki hasil yang berbeda-beda. Terdapat interaksi antara jenis pakan dan jenis media berpengaruh sangat nyata terhadap variabel $\mathrm{pH}-\mathrm{H}_{2} \mathrm{O}$ dan bobot cacing tanah Lumbricus rubellus dan pada faktor tunggal yaitu pada variabel P-Bray, Ca-dd dan Na-dd. Sedangkan pada variabel N-total, C-organik, K-dd dan KTK tidak terdapat pengaruh yang nyata.

2. Terdapat interaksi antara jenis pakan dan jenis media berpengaruh sangat nyata terhadap bobot akhir cacing tanah Lumbricus rubellus yaitu pada perlakuan P1G1 dengan bobot 155,77 gram, pada perlakuan P1G0 dengan bobot 105,58 gram, dan pada perlakuan P2G0 dengan bobot 90,83 
gram, dan bobot cacing tanah Lumbricus rubellus tidak berpengaruh nyata yaitu pada perlakuan P2G1 dengan bobot 47,56 gram.

\section{Daftar Pustaka}

Arifah, S.M. 2014. Analisis Komposisi Pakan Cacing Lumbricus sp. Terhadap Kualitas Kascing Dan Aplikasinya Pada Tanaman Sawi. Malang. Volume 9, Nomor 2 Jurnal Gamma, ISSN 02168995

Brata. 2009. Cacing Tanah Faktor Mempengaruhi Pertumbuhan dan Perkembangbiakan. IPB Press. Bandung

Catalan, G.I. 1981. Earthworms a New-Resource of Protein. Philippine Earthworm Center. Philippines.

Djuarnani, N., Kristian, dan Setiawan. B. D, 2005. Cara Cepat Membuat Kompos. Cetakan Pertama. Agromedia Pusaka. Jakarta

Djuarnani, N., Kristian, dan Setiawan. B. D, 2005. Cara Cepat Membuat Kompos. Cetakan Pertama. Agromedia Pusaka. Jakarta

Embleton, T.W., et al., 1973. Leaf Analysis as a Diagnotic Tool and Guide to Fertilization. In W. Reater (Ed.). The Citrus Industry. Rev. Ed. Univ Calif. Agr. Sci. Barkely. 3:183-210.

Indriani, Y.H. 2007. Membuat Kompos Secara Kilat. Penebar Swadaya. Jakarta.

Lavelle, P. 1988. Potential use ofearthworms in tropical soils.In Edward and Neuhauser (Eds.). Earthworm in Waste and Environmental Management. SPB Academic Publ., the Hague, the Nederlands. p. 273-279.

Mashur, 2001. Vermikompos Pupuk Organik Berkualitas dan Ramah Lingkungan. Instalasi Penelitian dan Pengkajian Teknologi Pertanian Badan Penelitian dan Pengembangan Pertanian. Mataram.

Mashur, 2001. Vermikompos Pupuk Organik Berkualitas dan Ramah Lingkungan. Instalasi Penelitian dan Pengkajian Teknologi Pertanian Badan Penelitian dan Pengembangan Pertanian. Mataram.

Mursining, 2006. Teknik Pembesaran Ikan Kelemak Leptobarbus hoeveni Blkr dengan Pemberian Kombinasi Pakan Berbeda. Skripsi. Fakultas Perikanan dan Ilmu Kelautan. Universitas Riau. Pekanbaru.

Palungkun, 2010. Usaha Ternak Cacing Tanah Lumbricus rubellus, Penebar Swadaya, Jakarta

Pandebesie, E.S., Rayuanti, D,. 2013. Pengaruh Penambahan Sekam Pada Proses Pengomposan Sampah Domestik. Jurnal Lingkungan Tropis. 6 (1) $31-40$.

Subler S, Parmelee RW and Allen MF. 1998. Functionaldiversity of decomposer organism in relation toprimary production. App. Soil Ecol. (9) :25-31

Sutanto, 2002. Faktor Penentu Kualitas Kompos.

Suyono dan Aisyah. 2000. Kandungan Hara N, P, dan K pada Cacing Lumbricus rubellus yang Dibudidayakan dengan Pakan Limbah Organik. Journal SoilRens. 1(1) : 24-28.

Thomson, L.M and F.R. Troeh. 1978. Soil Fertility. New York. Mc Graw-Hill Book Company. 368 p.

Warsa, 2000. Pertumbuhan dan Perkembangan Lumbricus rubellus yang Dibudidayakan dengan Enam Pakan Limbah Organik, Journal Soil Rens, 1(2), 61-67.

Wiriano, 1985. Pemanfaatan Ampas Tahu Menjadi Berbagai Macam Makanan. Laporan Penelitian. Balai Besar Penelitian dan Pengembangan Industri Hasil Pertanian. Bogor. 